\title{
Sperm penetration in vitro of pig follicular oocytes matured in culture
}

\author{
A. Iritani, K. Niwa and H. Imai \\ Department of Animal Science, College of Agriculture, Kyoto University, Kyoto 606, Japan
}

\begin{abstract}
Summary. Boar ejaculated and epididymal spermatozoa were preincubated in modified KRB or the isolated oviduct and uterine horn of an oestrous sow for $4 \cdot 5-5 \mathrm{~h}$ at $37^{\circ} \mathrm{C}$ before introduction into medium containing ovarian oocytes previously cultured for $24 \mathrm{~h}$. At examination $17-20 \mathrm{~h}$ after insemination $60.6 \%$ of the total oocytes had reached at least the 2 nd metaphase. The proportions of oocytes penetrated (i.e. enlarged sperm head or male pronucleus and corresponding sperm tail) were $0,10.0$ and $16.7 \%$ with ejaculated spermatozoa, and $3.3,19.6$ and $26.4 \%$ with epididymal spermatozoa preincubated in modified KRB, oviduct and uterus, respectively. Although the proportion of oocytes with morphologically normal male and female pronuclei was low $(10 / 36=27 \cdot 8 \%)$, the results suggest that boar spermatozoa can be capacitated in the isolated genital tract of an oestrous sow and that capacitation of epididymal is better than that of ejaculated spermatozoa.
\end{abstract}

\section{Introduction}

The maturation of follicular oocytes in culture followed by sperm penetration in vitro has been reported for the mouse (Cross \& Brinster, 1970; Iwamatsu \& Chang, 1972, Mukherjee; 1972), rat (Niwa \& Chang, 1975; Niwa, Miyake, Iritani \& Nishikawa, 1976), hamster (Barros \& Munoz, 1974), guinea-pig (Yanagimachi, 1974), rabbit (Brackett, Mills \& Jeites, 1972), cattle (Iritani \& Niwa, 1977) and man (Edwards, Bavister \& Steptoe, 1969). Although Motlik \& Fulka (1974) reported the successful fertilization of pig follicular oocytes matured in culture after transfer to mated animals, we have been unable to find any report on the fertilization in vitro of pig oocytes matured in culture. The present experiment was to examine the possibility of capacitation of boar epididymal and ejaculated spermatozoa in reproductive tracts isolated from oestrous sows by using procedures similar to those in experiments with cattle oocytes (Iritani \& Niwa, 1977).

\section{Materials and Methods}

Culture of follicular oocytes. Ovaries were removed from prepubertal Landrace gilts weighing 80 $100 \mathrm{~kg}$ at a local slaughterhouse and returned to the laboratory in saline $(0.154 \mathrm{M}-\mathrm{NaCl})$ at $30^{\circ} \mathrm{C}$ within $1 \mathrm{~h}$. Oocytes at the germinal vesicle stage were collected by puncturing follicles which had diameters of $2-3 \mathrm{~mm}$. The oocytes with cumulus cells were washed twice with saline, and groups of 10-15 were cultured for $24 \mathrm{~h}$ at $37^{\circ} \mathrm{C}$ in an atmosphere of $5 \% \mathrm{CO}_{2}$ in air in $0.4 \mathrm{ml}$ modified Kreb'sRinger-bicarbonate solution (modified KRB containing $94.6 \mathrm{mM}-\mathrm{NaCl}, 4.78 \mathrm{~mm}-\mathrm{KCl}, 1.71 \mathrm{mM}$ $\mathrm{CaCl}_{2}, 1.19$ mM- $\mathrm{KH}_{2} \mathrm{PO}_{4}, 1.19 \mathrm{~mm}-\mathrm{MgSO}_{4}, 25.07 \mathrm{~mm}-\mathrm{NaHCO}_{3}, 21.58 \mathrm{~mm}$-sodium lactate, $0.5 \mathrm{~mm}-$ sodium pyruvate, $5.56 \mathrm{~mm}$-glucose, $1 \mathrm{mg}$ crystalline bovine serum albumin $/ \mathrm{ml}, 50 \mu \mathrm{g}$ streptomycin sulphate $/ \mathrm{ml}$ and $75 \mu \mathrm{g}$ potassium penicillin $/ \mathrm{ml}$ ) covered with warm paraffin oil.

Preincubation of spermatozoa. Semen was collected from two Landrace boars by the glove method, filtered through double gauze to remove the gel and about $10 \mathrm{ml}$ semen were washed once with modified KRB. The washed spermatozoa were resuspended in $5 \mathrm{ml}$ modified KRB. Epididymal spermatozoa were collected from the cauda epididymidis immediately after slaughter, and about $2 \mathrm{ml}$ semen were suspended in $5 \mathrm{ml}$ modified $\mathrm{KRB}$. In one of the 3 trials of the present experiments ejaculated and 
epididymal spærmatozoa were collected from the same boar before and after slaughter. Ejaculated and epididymal sperm samples were preincubated as follows: one of three portions of the sperm sample was incubated for $4 \cdot 5-5 \mathrm{~h}$ in modified KRB (control), and two portions were incubated for $4.5-5 \mathrm{~h}$ in the isolated genital tract from an oestrous sow obtained from the slaughterhouse. These times were based on that known to be required for capacitation of boar spermatozoa (Hunter, 1972; Hunter, Holtz \& Henfrey, 1976). The integrity of the follicles and the oestrous condition of the sows were carefully checked. The volume of sperm suspension and the number of spermatozoa incubated were $0.1 \mathrm{ml}$ and $4 \times 10^{7}$ in $0.5 \mathrm{ml}$ modified $\mathrm{KRB}$ and in an oviduct, and $0.5 \mathrm{ml}$ and $2 \times 10^{8}$ in a uterine horn. After the introduction of spermatozoa, the ovarian end of the oviduct, the uterotubal junction and the cervical end of the uterus were ligated, and the tract was kept in saline for $4.5-5 \mathrm{~h}$ at $37^{\circ} \mathrm{C}$. After incubation the spermatozoa were recovered by flushing the oviducts and uteri. Contaminating blood cells and epithelial cell debris were removed by centrifugation at $150 \mathrm{~g}$ for $5 \mathrm{~min}$, and then the spermatozoa were washed by centrifugation at $500 \mathrm{~g}$ for $10 \mathrm{~min}$. The motility of the spermatozoa decreased slightly after incubation in modified $\mathrm{KRB}$, and was poor when they were recovered from the reproductive tracts. The motility, however, always improved after washing although it was not better than that of spermatozoa incubated in modified KRB. The motility that was present was retained until $17-20 \mathrm{~h}$ after insemination.

Fertilization in vitro and examination of oocytes. About $10 \mu \mathrm{l}$ sperm suspension $\left(0.5-1 \times 10^{6}\right.$ spermatozoa $/ \mathrm{ml}$ ) were introduced into the $0.4 \mathrm{ml}$ medium containing the $10-15$ cultured oocytes. The oocytes and spermatozoa were cultured for $17-20 \mathrm{~h}$ at $37^{\circ} \mathrm{C}$ and then the oocytes were fixed for $4-5$ days in $25 \%$ acetic alcohol at room temperature and stained with $1 \%$ aceto-orcein for examination by phase-contrast microscopy. Those undergoing fertilization according to the criteria shown in Plate 1 were identified.

\section{Results}

As shown in Table 1, 60.6\% oocytes matured to at least the second metaphase. Penetration by spermatozoa preincubated in modified KRB was very low or absent. Eggs incubated with spermatozoa (ejaculated or epididymal) preincubated in the isolated oviduct or uterus showed clear signs of penetration and activation (Table 1 and $\mathrm{Pl}$. 1, Figs 1, 2, 3, 4, 5 and 6). The 2 polyspermic eggs were associated with 4-5 spermatozoa; there were 4-5 pronuclei, corresponding sperm tails, a female nucleus of condensed chromatin and a second polar body (Pl. 1, Fig. 4).

\section{EXPLANATION OF PLATE 1}

Fig. 1. The fertilizing spermatozoon in an oocyte fixed $17 \mathrm{~h}$ after the introduction of epididymal spermatozoa preincubated in the isolated uterus from an oestrous sow for $5 \mathrm{~h}$. The nuclear swelling and the detached midpiece are seen. $\times 900$.

Fig. 2. An egg showing the sperm mid-piece (arrow), the sperm head $(\mathrm{H})$, the female nuclear mass $(\mathrm{F})$ and the polar body (PB), probably the first. The egg was fixed $20 \mathrm{~h}$ after the introduction of ejaculated spermatozoa preincubated for $4.5 \mathrm{~h}$ in the isolated uterus from an oestrous sow. $\times 700$.

Fig. 3. The fertilizing spermatozoon in an oocyte fixed $17 \mathrm{~h}$ after the introduction of ejaculated spermatozoa preincubated in the isolated oviduct from an oestrous sow. The detached mid-piece (arrow) and the enlarged sperm head $(\mathrm{H})$ are seen. $\times 680$.

Fig. 4. An egg showing polyspermic fertilization: 4 male pronuclei (arrows; distribution of chromatin looks abnormal) can be seen, and the second polar body and the female nuclear mass (asynchronous development with male pronucleus) were also present in a different focal plane. The egg was fixed $20 \mathrm{~h}$ after the introduction of epididymal spermatozoa preincubated for $5 \mathrm{~h}$ in the isolated oviduct from an oestrous sow. $\times 640$.

Figs 5 and 6. A pronuclear egg fixed $17 \mathrm{~h}$ after the introduction of epididymal spermatozoa preincubated in the isolated uterus from an oestrous sow. Both the female $(F)$ and the male $(M)$ pronuclei (distribution of chromatin looks abnormal) are seen in Fig. $5(\times 700)$. The arrow shows the location of the sperm tail (Fig. 6 , $\times 890)$ in a different focal plane near the male pronucleus $(M)$ in Fig. 5. 
PLATE 1
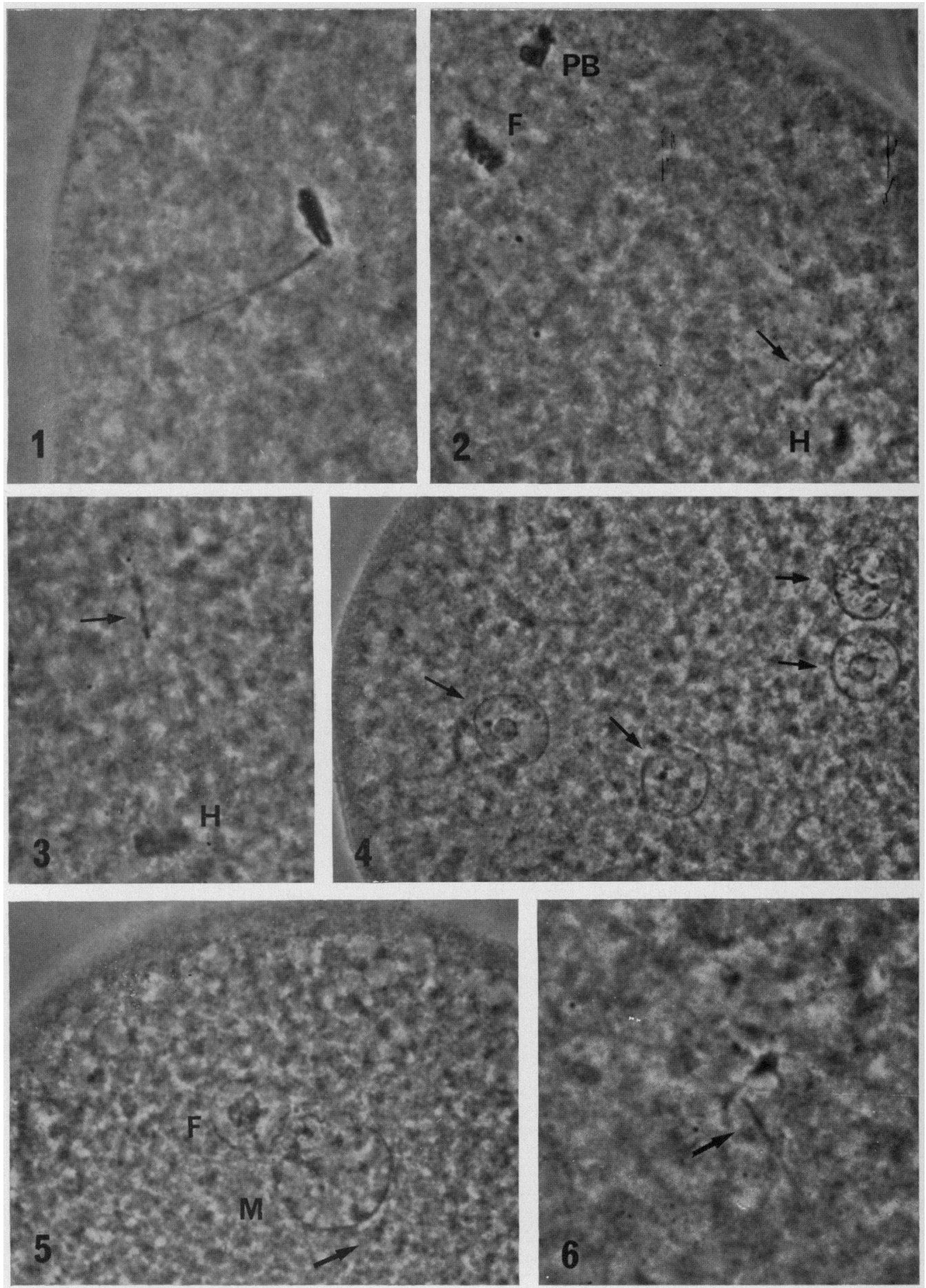
Penetration of pig oocytes in vitro

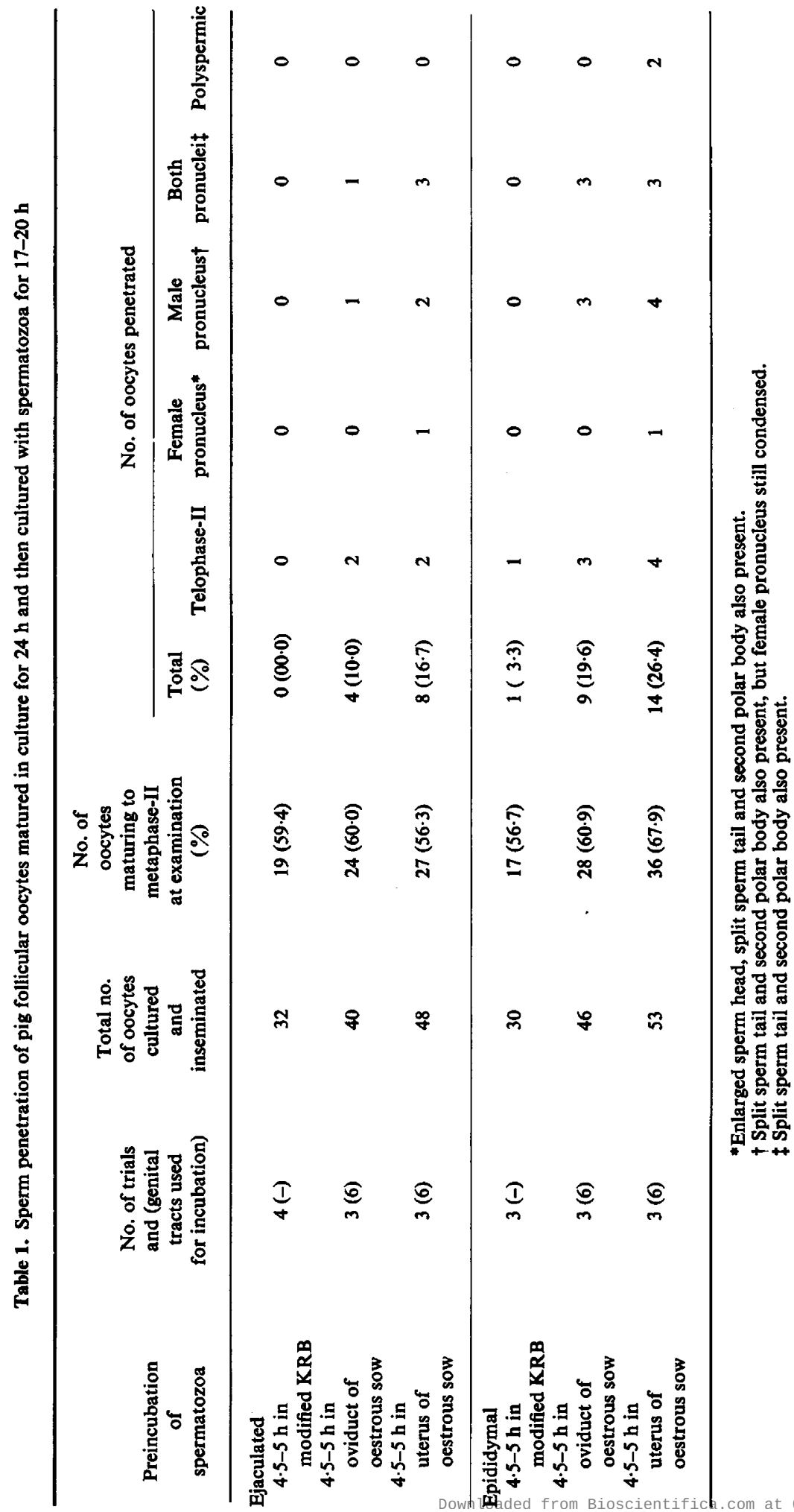




\section{Discussion}

The maturation rate to the second metaphase, $60.6 \%$, was comparable to that of $60.9 \%$ which was obtained in previous experiments in which the culture period was up to $48 \mathrm{~h}$ (Sato, Iritani \& Nishikawa, 1978).

Boar spermatozoa require $4 \mathrm{~h}$ to become fully capacitated in the uterus in vivo (Hunter \& Hall, 1974). The present study shows that the preincubation period of $4.5-5 \mathrm{~h}$ in the isolated uteri from oestrous sows was also effective for capacitation, although the proportion of oocytes penetrated was relatively low. It is possible that although some spermatozoa do become capacitated in the isolated reproductive tract full capacitation does not occur until later when the eggs and spermatozoa are being incubated together. However, it might be expected that washing of the spermatozoa and removal of the seminal plasma, which may be detrimental to the sperm cells, would be beneficial and counteract the poorer ability of the isolated tract to capacitate spermatozoa than occurs in vitro.

The oviduct appeared to be less effective for capacitation than the uterus for preincubation of spermatozoa, but the differences were not significant, as found for rabbits (Bedford, 1969) and cattle (Iritani \& Niwa, 1977). The slightly higher proportion of oocytes penetrated by epididymal than ejaculated spermatozoa indicates that sperm-coating factors may be involved in the poorer capacitation of ejaculated spermatozoa, as suggested by Hunter et al. (1976).

The problem of the normality of oocytes fertilized in vitro has often been raised. In the mouse only $3 \%$ of oocytes fertilized after maturation in vitro developed normally after being transferred into recipients (Cross \& Brinster, 1970). Low proportions of penetrated oocytes developing into normal 2-cell stages have been reported for rat oocytes matured in culture (Niwa \& Chang, 1975). Delayed and abnormal transformation of the sperm head into a pronucleus in oocytes matured in culture have been found for rabbits (Thibault, 1973), but not for rats (Niwa \& Chang, 1975) or guinea-pigs (Yanagimachi, 1974). In the present study with pig oocytes matured in culture, various abnormalities, such as asynchronous development of the male and female pronuclei (PI. 1, Fig. 4), and delay (Pl. 1, Figs 2 and 3) or abnormal transformation (Pl. 1, Figs 4 and 5) of the sperm head into a pronucleus, were frequently observed. This may be due to the lack or insufficient synthesis of a 'male pronucleus growth factor' as suggested by Thibault (1973) for rabbit oocytes matured in culture.

This work was supported by a grant from the Ford Foundation (No. 740-0404). One of us (A.I.) is a recipient of a grant from the Ministry of Education of Japan (No. 256199).

\section{References}

Barros, C. \& MUNOZ, C. (1974) Sperm penetration through the zona pellucida of immature hamster oocytes. Acta physiol. latinoam. 24, 612-615.

BEDFORD, J.M. (1969) Limitations of the uterus in the development of the fertilizing ability (capacitation) of spermatozoa. J. Reprod. Fert., Suppl. 8, 19-26.

BracketT, B.G., Mills, J.A. \& Jeites, G.G. (1972) In vitro fertilization of rabbit ova recovered from ovarian follicles. Fert. Steril. 23, 898-909.

Cross, P.C. \& Brinster, R.L. (1970) In vitro development of mouse oocytes. Biol. Reprod. 3, 298-307.

Edwards, R.G., Bavister, B.D. \& Steptoe, P.C. (1969) Early stages of fertilization in vitro of human oocytes matured in vitro. Nature Lond. 221, 632-635.

HuNTER, R.H.F. (1972) Fertilization in the pig: sequence of nuclear and cytoplasmic events. $J$. Reprod. Fert. 29, 395-406.

HuNTER, R.H.F. \& HALl, J.P. (1974) Synergism between uterine and tubal environments. J. exp. Zool. 188, 203-214.
Hunter, R.H.F., Holtz, W. \& Henfrey, P.J. (1976) Epididymal function in the boar in relation to the fertilizing ability of spermatozoa. J. Reprod. Fert. 46, $463-466$.

IRITANI, A. \& NiwA, K. (1977) Capacitation of bull spermatozoa and fertilization in vitro of cattle follicular oocytes matured in culture, J. Reprod. Fert. 50, 119-121.

IWAMaTSU, T. \& ChaNG, M.C. (1972) Sperm penetration in vitro of mouse oocytes at various times during maturation. J. Reprod. Fert. 31, 237-247.

Motlik, J. \& FulkA, J. (1974) Fertilization of pig follicular oocytes cultivated in vitro. J. Reprod. Fert. 36, 235-237.

MukherJee, A.B. (1972) Normal progeny from fertilization in vitro of mouse oocytes matured in culture and spermatozoa capacitated in vitro. Nature, Lond. 237, 397-398.

Niwa, K. \& Chang, M.C. (1975) Fertilization of rat eggs in vitro at various times before and after ovula- 
tion with special reference to fertilization of ovarian oocytes matured in culture. J. Reprod. Fert. 43, 435451.

Niwa, K., Miyake, M., Iritani, A. \& Nishikawa, Y. (1976) Fertilization of rat oocytes cultured in vitro from various stages of maturation. J. Reprod. Fert. 47, 105-106.

Sato, E., Iritani, A. \& Nishikawa, Y. (1978) Rate of maturation division of pig follicular oocytes. Jap. J. zootech. Sci. 49, 400-405.
ThibaulT, C. (1973) In vitro maturation and fertilization of rabbit and cattle oocytes. In The Regulation of Mammalian Reproduction, Ch. 17, pp. 231-240. Eds S. J. Segal, R. Crozier, P. A. Corfman \& P. G. Condliffe. C. C. Thomas, Springfield, Illinois.

YANAGIMACH, R. (1974) Maturation and fertilization in vitro of guinea-pig ovarian oocytes. J. Reprod. Fert. $38,485-488$.

Recelved 29 March 1978 